\title{
Wielka Brytania jako region pogranicza. Tożsamości i artykulacja interesów politycznych
}

\author{
Magdalena Katana ${ }^{1}$
}

\begin{abstract}
:
Great Britain as a borderland. Regional identities and political reality. The aim of this article is to look at the political reality of the United Kingdom of Great Britain and Northern Ireland from the perspective of borderlands understood as a result of political action, an area in which they are expressed, but at the same time are the driving force of these processes. Identities of borderlands play a significant role in shaping political reality in the UK. Their diversity, the strength of their interests' articulation, participation in political rivalry, although it was not the only factor, have determined the current political system of the state to a large extent. At the same time the impact of political transformations on changes in the identities is noticeable. More and more of them, in addition to their own national/regional identification, also indicates the relationship with the United Kingdom as a whole, which suggests that devolution rather strengthens the state, than leads towards disintegration, although such a risk exists in reality.
\end{abstract}

Keywords:

Great Britain, devolution, national identity, England, Scotland, Wales, Northern Ireland

Streszczenie:

Celem artykułu jest spojrzenie na rzeczywistość polityczna Zjednoczonego Królestwa Wielkiej Brytanii i Irlandii Pólnocnej z perspektywy pogranicza. Jest ono rezultatem działań politycznych, obszarem, $w$ którym znajdują one swój wyraz, ale i na zasadzie sprzężenia zwrotnego są siłą napędowa tych procesów. Tożsamości pogranicza w Wielkiej Brytanii odgrywaja znaczaca rolę w ksztaltowaniu rzeczywistości politycznej. Ich zróżnicowanie, siła artykulacji interesów, uczestnictwo w rywalizacji politycznej, w dużej mierze, choć nie byt to czynnik jedyny, przesadziły o obecnym kształcie ustrojowym państwa. Jednocześnie zauważalny jest, subtelny na razie, wpływ przeobrażeń ustrojowych na zmiany tożsamości. Coraz więcej mieszkańców, obok identyfikacji narodowej/regionalnej, wskazuje także na związi z Wielką Brytania jako całościa, co świadczy o tym, że Zjednoczone Królestwo, dzielac się władzą raczej umacnia państwo niż prowadzi je ku rozpadowi, choć takie ryzyko przy dewolucji w brytyjskich warunkach istnieje.

\section{Słowa kluczowe:}

dewolucja, Wielka Brytania, tożsamość narodowa, Szkocja, Anglia, Walia, Irlandia Północna

Link do artykułu:

http://pogranicze.uni.opole.pl/biblioteka/docs/nr1/katana_nr1.pdf

Standard cytowania (APA):

Katana, M. (2013). Wielka Brytania jako region pogranicza. Tożsamości i artykulacja interesów politycznych. Pogranicze. Polish Borderlands Studies, nr 1, s. 91-105.

\section{Wstęp}

Podjęcie próby uczynienia kategorii pogranicza i wszystkiego, co się z nim wiąże, punktem wyjścia w badaniach rzeczywistości politycznej jest zadaniem dość ambitnym. W pierwszym momencie propozycja ta budzi konsternację, chociażby $\mathrm{z}$ uwagi na stan wiedzy w zakresie teorii pogranicza. Sam termin nie doczekał się przecież dotychczas jednolitej interpretacji, zaś kryteriów klasyfikacyjnych pozwalających wyodrębnić rodzaje pogranicza stale przybywa.
Ponadto, chociaż zagadnienie znajduje się w orbicie zainteresowań wielu dyscyplin (m.in. geografia, historia, etnografia, socjologia), nie zostało ono włączone do żadnej z nich, lecz stało się przedmiotem interdyscyplinarnych dyskusji, a więc paradoksalnie pograniczem różnych nauk. Brak jednolitej teorii, zaplecza definicyjnego oraz ścisłe powiązanie z problematyką pojęć pokrewnych, takich jak ,granice”, „nadgranicze”, ,przygranicze” $i$, transgranicze”

$\overline{1}$ Magdalena Katana: absolwentka Wydziału Prawa, Administracji i Ekonomii Uniwersytetu Wrocławskiego. 
czynią tę kwestię jeszcze bardziej skomplikowaną. Nie oznacza to jednak, że jest to zadanie niemożliwe. Niemal 30 lat temu francuski historyk Pierre Vilar stwierdził, że historię świata najlepiej widać z granic/pograniczy ${ }^{1}$. Wydaje się więc, że nic nie stoi na przeszkodzie, by również dzieje państwa i jego ustroju analizować przez ich pryzmat.

Celem niniejszych rozważań jest spojrzenie na rzeczywistość polityczną Zjednoczonego Królestwa Wielkiej Brytanii i Irlandii Północnej z perspektywy pogranicza. Państwo to nie tylko geograficznie jest oddzielone od reszty kontynentu, ale i jego historia czyni je wyjątkowym. Obejmuje ono cztery samodzielne terytoria (Anglia, Szkocja, Walia i Irlandia Północna) zamieszkane przez pięć (uznanych) grup narodowościowych: Anglików, Brytyjczyków, Szkotów, Walijczyków i Irlandczyków Północnych. Nie byłoby w tym nic dziwnego, w Europie wielonarodowość wpisana jest w funkcjonowanie wielu państw, gdyby nie ustrój polityczny. Wielka Brytania jest unią realną wymienionych czterech części składowych. Formalnie jest to państwo unitarne, ale o silnym stopniu decentralizacji (a nie zawsze tak było), ponieważ terytoria dysponują dość daleko idącą możliwością decydowania o swoich sprawach. W Zjednoczonym Królestwie usankcjonowano odrębności terytorialne (i związane z nimi identyfikacje etniczne/ narodowościowe) poprzez cesję uprawnień centralnych. Jednak, w odróżnieniu od innych państw, gdzie zastosowano model federacji, odgórnego podziału obejmującego także część suwerennych praw, w Wielkiej Brytanii przeprowadzono dewolucję. To pewnego rodzaju daleko idąca (Czapiewski 2011) decentralizacja władzy w państwie unitarnym, polegająca na przekazaniu podporządkowanemu organowi, pochodzącemu z wyborów opartych na kryterium geograficznym, funkcji wykonawczych pełnionych dotychczas przez ministrów i Parlament Zjednoczonego Królestwa (Bogdanor 2001). Inaczej niż w państwie

$1 \quad$ Autor użył terminu frontier, co stanowi pewien problem terminologiczny, który należy wyjaśnić, jednak niezależnie od ustaleń w tej materii, z uwagi na pokrewieństwo etymologiczne granicy i pogranicza, twierdzenie to można zaadaptować do badań w zakresie nauk politycznych. federalnym, nastąpiło to niejako „od dołu ku górze", przy czym suwerenność nadal przysługuje państwu. Zatem, jak to ujął Tomasz Czapiewski, „znaczenie dewolucji opiera się na dwóch sprzecznych zasadach: suwerenności i supremacji Parlamentu oraz samorządności w sprawach wewnętrznych Szkocji, Walii i Irlandii Północnej” (Czapiewski 2011: 12).

Należy też zauważyć, że o ile w innych krajach, nawet wielonarodowych, istnieje jedna dominująca tożsamość narodowa, w Wielkiej Brytanii sytuacja jest bardziej złożona. Dużą rolę odgrywa tu siła (lub słabość) tożsamości państwowej. W Zjednoczonym Królestwie dominująca narodowa tożsamość - angielska łączy się dość silnie z identyfikacją państwową - brytyjską (Tierney 2009), podczas gdy w innych częściach Zjednoczonego Królestwa, gdzie tożsamość etniczna/narodowa opiera się o negację „angielskości”, także „brytyjskość”, która ma wyrażać jedność kraju, ma, przynajmniej na razie, znikome (chociaż podlegające pewnym ciekawym zmianom) znaczenie.

Nie bez znaczenia jest, że Anglicy stanowią 84 proc. populacji Zjednoczonego Królestwa. Znalazło to wyraz w asymetrii rozwiązań dewolucyjnych. Każde z terytoriów otrzymało tyle swobody i w takim zakresie, jaki był mu potrzebny. Tymczasem to właśnie Anglia jest jedynym, którego dewolucja nie objęła, gdyż nie wydawało się to konieczne. Należy też wziąć pod uwagę, że ani Szkocja ani Walia nie mają odniesienia do żadnego istniejącego współcześnie państwa, inaczej zaś Irlandia Północna, historycznie związana z Irlandią. Należałoby zbadać specyfikę wymienionych tożsamości, by określić, na czym się opierają, jaki jest ich charakter i w jaki sposób determinują rzeczywistość polityczną, przez chociażby poparcie (bądź nie) dla dewolucji.

Ponadto, nie tylko chęć zarządzania zróżnicowaniem narodowościowym wewnątrz terytorium stanowiła przesłankę dewolucji. $\mathrm{Z}$ pewnością chodzi też o sprawne zarządzanie państwem, bo dewolucja jest wartością samą $\mathrm{W}$ sobie, lokując podejmowanie decyzji na innych niż centralny szczeblach, a poprzez to wzmacnia demokrację i realizuje zasadę pomocniczości. Nie można więc wykluczyć - a nawet należy go uwzględnić - wpływu 
globalizacji i towarzyszącego jej procesu regionalizacji, indywidualizacji, tendencji do instytucjonalizacji pośredniego szczebla administracji publicznej, na efektywniejszą realizację celów administracji centralnej (Cole 2006). Z drugiej strony lepiej było podzielić się władzą, niż utracić ją całkowicie.

Nie ulega wątpliwości, że opisane rozwiązania polityczne determinuje specyfika pogranicza. Istnienie pograniczy jest rezultatem działań politycznych, obszarem, w którym znajdują one swój wyraz, ale i - na zasadzie sprzężenia zwrotnego - jest siłą napędową tych procesów. Jako pewien terytorialny układ strukturalny wraz z dynamiką jego zmian i całokształtem międzyludzkich kontaktów, a więc ład powstały w ich wyniku (Sadowski, 2008), z całą pewnością może być rozważany politycznie. Ludność pogranicza artykułuje pewne potrzeby, które stają się interesami politycznymi, a dla ich realizacji uczestniczy ona $\mathrm{w}$ rywalizacji politycznej, determinując rozwiązania polityczne w całości terytorium państwa.

W 2014 roku Wielką Brytanię czeka referendum, w którym Szkocja zdecyduje, czy chce dalej korzystać z dewolucji, poszerzając jej zakres, czy uniezależnić się i zdestabilizować unię (Black 2011). Ponadto, żądania autonomii coraz wyraźniej wysuwa także Kornwalia (Ferguson 2009; Deacon, Cole, Tregidga 2003). Dewolucja w brytyjskim wydaniu to proces zainicjowany przez kultury pogranicza. Może wzmocnić Unię przez to, że uwzględnia odrębności, ale stwarza jednocześnie okazję do separatyzmu. Czy odmienności terytorialno-narodowościowe wpływają na przebieg procesu dewolucji i czy, a jeśli tak, to jak oddziałuje on na nie zwrotnie?

\section{Pogranicza - symbole i obszary władzy}

Trudno wyobrazić sobie przeprowadzenie analizy dotyczącej wpływu pogranicza na rzeczywistość polityczną bez zidentyfikowania głównego punktu rozważań. Jak już zasygnalizowano we wstępie, zadanie to nie będzie łatwe. Pozornie prosty koncept pogranicza doznaje komplikacji już na etapie budowania zaplecza terminologicznego. Chociaż żadne pogłębione analizy w tej materii nie stanowią przedmiotu niniejszych rozważań, warto wskazać na podstawowe pojmowanie pogranicza oraz umiejscowić tę kategorię jako punkt wyjścia dla dalszych rozważań.

Etymologia pojęcia oraz słownikowa jego definicja określająca pogranicze jako „teren wzdłuż granicy, obszar wyodrębniający się naturalnie, historycznie, kulturowo, itp. lub obszar wyodrębniony administracyjnie" (Dunaj 1998: 93) pozwalają na stwierdzenie związków terminu $\mathrm{z}$ pojęciem granicy. Ta ostatnia to „miejsce, gdzie kończy się jakiś obszar, linia oddzielająca obszar od innego, umowna linia oddzielająca terytoria, linia podziału, czynniki różnicujące zjawiska, ograniczony zasięg, zakres czegoś, kres możliwości” (tamże: 286). Nie są to terminy tożsame. W języku polskim różnicę widać dość wyraźnie, a przynajmniej jest ona wyczuwana intuicyjnie. Tymczasem w języku angielskim sytuacja jest nieco bardziej złożona. Funkcjonują w nim pojęcia: „border”, „,boundary”, „,borderline”, ,frontier" i ,borderlands". „Border", czyli granica, oznacza linię separującą dwa państwa, albo obszary niekoniecznie fizyczne. Granica, dopiero postrzegana jako strefa, określana jest pograniczem „,borderland(s)". Jednak w literaturze przedmiotu w tym kontekście pojawia się także słowo ,frontier". Problem z tym pojęciem polega na zamiennym używaniu go (głównie przez amerykańskich autorów) jako synonimu granicy albo na określaniu nim pogranicza, jeśli jest to obszar wokół granicy. To strefa kontaktu z, albo bez wyraźnego (fizycznego, albo symbolicznego) odgraniczenia wskazującego na podział przestrzenny (science.jrank.org 2013). Pogranicze często określane jest także metaforycznie jako każda granica między znanym i nieznanym, „swoim” a „obcym” (Gątkiewicz, Kocoń, Skowron 2013). To miejsca szczególne, tak realne, jak i symboliczne, gdzie obserwuje się konflikt, adaptację, przenikanie.

Powyższe ustalenia są o tyle istotne, że - poprzez powiązanie z kategorią granicy pozwalają umieścić pogranicze $\mathrm{w}$ pewnym kontekście politycznym. Granica jest przecież elementem organizacji przestrzeni, wyrazem instytucjonalizacji terytorium, a więc wykazuje związki z kategorią tożsamości, władzy i suwerenności. Owe realne granice niekoniecznie pokrywają się z tymi w świadomości ludzkiej. 
Bez wątpienia pogranicze, które ma pierwotny wobec granicy charakter, jest tworem politycznym (Simonides 1994: 94). W literaturze przedmiotu pojawia się wiele definicji pogranicza przydatnych w rozważaniach politologicznych. To, jak podkreśla Andrzej Sadowski, ,zagęszczenie granic politycznych, historycznych, społeczno-kulturalnych, religijnych i etnicznych, które stanowią czynne (będące składnikiem współczesnej świadomości lub pamięci społecznej mieszkańców danego obszaru) wyposażenie kulturowe mieszkańców" (Sadowski 2008: 20). Z kolei Thomas M. Wilson i Hastings Donnan wskazują, że pogranicza to miejsca i procesy tożsamości i polityki, pełniące istotną rolę $\mathrm{w}$ kształtowaniu relacji pomiędzy tożsamością, terytorium i suwerennością (Wilson, Hastings 2012). Podobnie uważa Anna Ball, podkreślając, że pogranicze to nie tylko geograficzna struktura, ale struktura władzy, gdzie ujawnia się arbitralną budowę zarówno terytorium, jak i tożsamości kulturowej (Ball, 2005).

Polityczny wymiar pogranicza uważać należy za rezultat istnienia tożsamości zbiorowych, także tych regionalnych będących odmianą tożsamości społecznej i kulturowej, funkcjonujących w oparciu o wspólne lub zbliżone dla wszystkich, albo większości aktorów systemy wartości, norm, obyczajów, zwyczajów, języków, gospodarki, określonego terytorium (Bokszański 1989). To nie tylko miejsce, ale społeczne procesy. Przedstawiciele nauki zauważają, że ,pogranicze jest fizycznie obecne zawsze, gdy dwie albo więcej kultur się zazębia, styka, ludzie różnych ras zajmują to samo terytorium, gdzie stykają się klasy i gdzie przestrzeń pomiędzy dwiema jednostkami kurczy się rodząc zażyłość" (Anzaldūa 1999: 9), że jest to „leżący poza centrum obszar zróżnicowań, inności i odmienności, (...) obszar, na którym występuje określony typ stosunków międzyludzkich” (Simonides 1994: 46). Zdaniem Andrzeja Sadowskiego, właśnie na pograniczu instytucjonalizują się kontakty międzykulturowe. Analizując pogranicze, wskazuje on na istnienie pogranicza administracyjno-politycznego (granice wewnątrz państwa) oraz społecznego, dla identyfikacji którego wyodrębnić należy trzy ważne odrębne kategorie: społeczny obszar pogranicza, pograniczność oraz pogranicze (Sadowski 2008).

Społeczny obszar pogranicza to niejako baza, „wyodrębnione terytorium (przestrzeń), trwale zamieszkiwane przez przedstawicieli dwóch lub więcej zbiorowości społecznych, wyposażonych $\mathrm{w}$ możliwe do określenia odrębne kultury lub ich autonomiczne części, a przede wszystkim traktowane jako odrębne w społecznej świadomości" (Sadowski 2008: 19). Andrzej Sadowski określa elementy statyczne pogranicza takie jak struktura społeczna i kulturowa danego terytorium, stopień jego instytucjonalizacji. Dynamiczny wymiar pogranicza nazywa on pogranicznością i traktuje jako, ,przejaw wielości wysiłków jednostkowych i zbiorowych, skierowanych na przekraczanie granic, na poznanie innych $\mathrm{w}$ połączeniu $\mathrm{z}$ tworzeniem koniecznych ku temu warunków instytucjonalnych" (tamże: 22). Kategoria ta służy do określenia m.in. „treści społeczno-kulturowych dziejących się na pograniczach (...), związanych z zamieszkaniem tam przedstawicieli dwóch lub więcej kultur, (...) zabiegów o dominację, o wyjścia $\mathrm{z}$ sytuacji subordynacji, a także powiązań tych treści ze sferą ekonomiczną, polityczną, historyczną itp" (tamże). W dłuższej perspektywie charakter pograniczności na pograniczach wytwarza określony ład stosunków międzykulturowych, który można nazwać pograniczem społecznym.

Widać wyraźnie, że pogranicze to już nie tylko kategoria geograficzna, niejako peryferia organizmu państwowego (rubieże czy kresy), lecz twór funkcjonujący w określonej rzeczywistości politycznej $\mathrm{i}$ samo ma udział $\mathrm{w}$ jej tworzeniu. Według Iry Williama Zartmana jest to miejsce, w którym „państwo styka się ze społeczeństwem" (Zartman 2010: 3). Natomiast Thomas M. Wilson i Hastings Donnan uważają pogranicze za ,przestrzenne i czasowe sektory relacji pomiędzy lokalnymi społecznościami albo państwami”, gdzie nierzadko władza jest kwestionowana, grupy artykułują swoje interesy, negocjują relacje podporządkowania (Wilson i Donnan 2000: 23). Ci sami autorzy widzą w nim symbol zróżnicowania władzy państwa, instytucje społecznego przymusu, nawet sieci rywalizujące $\mathrm{z}$ państwem. Można zatem powiedzieć, że obszar pogranicza 
obejmuje przestrzeń społeczną oraz występujące tam struktury polityczne, ekonomiczne, społeczno-kulturowe oraz kontakty interkulturowe (Sadowski 2008). Kategoria pogranicza jest zatem bez wątpienia przydatna jako punkt wyjścia dla badań narodu i grup etnicznych (kulturowych), kontaktów (między)kulturowych, relacji etnicznych, zróżnicowanego pod wieloma względami społeczeństwa.

Spośród prezentowanych w literaturze poglądów warto wymienić ten Grzegorza Babińskiego, który $\mathrm{z}$ pojęciem pogranicza jako obszaru władzy, symbolu, wiąże pewną ideę, misję w odniesieniu do centrum. Według wspomnianego autora, ideologie pogranicza „Związane były zawsze z dążącymi do dominacji na tych obszarach zbiorowościami zewnętrznymi, najczęściej narodami, bądź z dążącymi do mniejszej czy większej autonomii zbiorowościami z obszarów pogranicza" (Romanowicz 2006: 201).

Definiowanie kategorii pogranicza, wraz z upływem czasu, podlega modyfikacjom. Jej rozumienie, od stricte geograficznego, opisującego obszar graniczny, zwykle na peryferiach państwa, ewoluowało odrywając się od granic politycznych i administracyjnych. Dotyczy po prostu obszarów państwa, w których istnieje wyraźna świadomość społecznej odrębności (Szczepański 1997). Ewoluowały też społeczności, które dążą do upodmiotowienia obszarów pogranicza poprzez programy regionalnej autonomii czy nawet politycznej odrębności (Romanowicz 2006). W rozważaniach o pograniczu zaczyna być widoczny regionalizm, mówi się o regionach pogranicza (Szczepański 1997). Wystarczy zwrócić uwagę na podobieństwo podstawowej interpretacji pogranicza do pojęcia regionu. W wydawnictwach encyklopedycznych, słownikach, leksykonach region określa się jako „wydzielony, stosunkowo jednorodny obszar odróżniający się od innych, przyległych terenów określonymi cechami naturalnymi lub nabytymi o różnym charakterze" (Petrozolin-Skowrońska 1996: 481). To twór czasowo-przestrzenny, oparty na istnieniu związków przyczynowo-skutkowych, w przeciwieństwie do pozostałych części obszaru lub strefy, istniejący niezależnie od podziałów instytucjonalnych obszar o określonym zespole cech, (obszar) zintegrowany pod względem wielu cech, które różnią go od obszarów sąsiednich (Leszczycki 1965).

Nietrudno też zauważyć, że istotnie na procesy warunkujące funkcjonowanie pogranicza oddziałuje polityka Unii Europejskiej wspierająca różnorodność, zwłaszcza tę kulturową, etniczną, tożsamościową, oraz regiony. Ta tendencja to tzw. idea mid-level (średniego poziomu) wpisana $\mathrm{w}$ regionalizm europejski, gdzie dla celów społeczno-ekonomicznych tworzy się możliwie jednorodne wewnętrznie jednostki administracyjne blisko szczebla centralnego jako ogniwa pośredniczące między państwem a lokalnymi społecznościami. Są to twory o mniejszej lub większej swobodzie. Niektóre z nich funkcjonują samodzielnie na forum Unii Europejskiej.

\section{Specyfika brytyjskiego pogranicza}

Analizując charakter pogranicza w Wielkiej Brytanii, należy uznać, że są to właściwie samodzielne regiony, których powstanie stanowi rezultat długotrwałych procesów tożsamościowych, wspieranych obecnie przez tendencje regionalne Unii Europejskiej. Bez wątpienia występuje tu element terytorium, więzi z nim, odrębności tożsamościowej. Nie są to regiony marginalizowane, na obrzeżach, lecz styk odmiennych tożsamościowo, politycznie i gospodarczo obszarów. Nie oddziela ich w zasadzie żadna granica, chociaż w świadomości nadal symbolami rozgraniczającymi są Mur Hadriana (dla Szkocji), Wał Offy (w przypadku Walii) oraz Kanał Świętego Jerzego, Morze Irlandzkie i Kanał Północny dla Irlandii Północnej.

$\mathrm{Na}$ czterech odrębnych terytoriach egzystuje pięć tożsamości. Zostaną one pokrótce przedstawione poniżej. Zanim to jednak nastąpi warto zauważyć, że w zasadzie większość tożsamości, choć wykazuje celtyckie pochodzenie, jest jednak odmienna. Inna w Szkocji, gdzie ma charakter bardziej obywatelski niż etniczny (Kalupa 2010), inna w Walii, gdzie zbudowana jest w oparciu o wspólnotę kultury i języka (Kaniasta 2010). W Irlandii Północnej zaś istotną rolę odgrywa pierwiastek etniczno - religijny. Ani Szkocja ani Walia nigdy nie 
tworzyły państwa. Inaczej jest w przypadku Irlandii Północnej, ponieważ ta część mieszkańców, która identyfikuje się z Irlandią, posiada państwo, z którym wiąże swoją historię. Wszystkie wymienione regiony bez wyjątku zbudowane są za to na zasadzie negacji tożsamości angielskiej, jednak, co ciekawe nie odrzucają „brytyjskości”. Ta rozumiana jest jako „legalno-instytucjonalne ramy funkcjonowania i specyficzne porozumienia, które łączą Zjednoczone Królestwo w całość. Wiąże się ją także z patriotyczną lojalnością wobec Korony, protestanckiej sukcesji i posłuszeństwem wobec prawa stanowionego przez parlament" (Kalupa 2010: 14). Tworzy to interesującą sytuację, w której tak rozumiane regiony pograniczne tworzą unię w takich, a nie innych warunkach politycznych.

Zgodnie z badaniem Census 2011 dla Wielkiej Brytanii, Anglicy stanowią 83,9 proc. populacji, Szkoci 8,4 proc., Walijczycy 4,8 proc., zaś Irlandczycy Północni 2,9 proc. (Office for National Statistics 2011). Jednak to nie dominująca grupa narodowa, lecz pozostałe, swoimi działaniami przyczyniły się do zmian ustrojowych w Zjednoczonym Królestwie.

Najliczniejszą po dominujących Anglikach grupą narodową są Szkoci. Anna Kalupa, dokonując wnikliwej analizy zagadnienia, wskazuje, że ich tożsamość narodowa nieustannie deprecjonuje wszystko co angielskie, eksponując różnice pomiędzy Szkotami i Anglikami w każdej dziedzinie. Chociaż funkcjonuje w oparciu o pamięć własnej przeszłości, własne punkty odniesienia, zarówno kulturowe, terytorialne, jak również społeczne i polityczne, to symbolika kulturowa ustępuje wspólnym wartościom obywatelskim i politycznym Szkotów. Jest to widoczne chociażby w tym, że języki narodowe gaelicki i szkocki, jako jedne z najważniejszych czynników umacniających tożsamość narodową, nie odgrywają znaczącej roli $\mathrm{w}$ procesie identyfikacji narodowej, ustępując językowi angielskiemu (Kalupa 2010).

Podobną zależność można zaobserwować w odniesieniu do religii. Chociaż dla szkockiej tożsamości narodowej niebagatelne znaczenie ma istnienie kościoła narodowego (Kirk), będącego największą wspólnotą wyznaniową w Szkocji (przynależność do niego deklaruje mniej więcej 40 proc. populacji), przestał on pełnić stricte religijne funkcje, choć nadal jest nośnikiem istotnych wartości. Z elementu kultury, Kirk stał się w dużej mierze instytucją społeczną o dość dużym znaczeniu, uczestniczącym w publicznych debatach dotyczących Szkocji, w tym dotyczących szkockiego statusu w ramach dewolucji (Keating 2001).

Wątpliwa siła oddziaływania tych czynników na tożsamość nie oznacza, że nie kultywuje się tradycji. Szkoci są postrzegani jako szczególnie aktywni w tym względzie, jednak w literaturze podkreśla się, że szkocka identyfikacja niewiele ma wspólnego z „dawną ludową pamięcią", raczej jej nośnikami są rozwinięte formy społeczeństwa obywatelskiego w postaci stowarzyszeń, organizacji odwołujących się do szkockich tradycji (Kalupa 2010).

Tożsamość Szkotów wyrażana jest także przez konkretne poglądy polityczne i wiąże się $\mathrm{z}$ udziałem $\mathrm{w}$ rywalizacji politycznej oraz konkretnymi wyborczymi zachowaniami, o których będzie mowa dalej. O identyfikacji narodowej w tej części Wielkiej Brytanii wiele mówią badania tożsamości. Wynika z nich, że ponad 70 proc. uczestników badania, postawionych przed wyborem jednej tylko tożsamości, wskazuje na szkocką (tab. 1).

Z danych wyraźnie wynika, że identyfikacja szkocka wypiera brytyjską - państwową. Ponad trzy razy więcej osób deklaruje się jako Szkoci niż Brytyjczycy. Na silne więzi ze Szkocją wskazują także badania, w których ankietowani mieli możliwość uszczegółowienia swoich postaw tożsamościowych (tab.2).

Jak wynika z zestawionych danych, zdecydowanie mały jest odsetek osób tożsamości „brytyjskiej nie szkockiej” i „bardziej brytyjskiej niż szkockiej”. Przeważają wskazania „,bardziej szkocka niż brytyjska” i „szkocka nie brytyjska".

Uważa się jednak, że tożsamość Szkotów należy określić bardziej jako regionalną niż narodową. Nie podkreślają oni bowiem etnicznego ekskluzywizmu. To także tożsamość obywatelska, gdzie licząsięzasady egalitaryzmu, otwartości, równości szans i godnego poziomu życia (Kalupa 2010). Przy tym, wziąwszy pod uwagę, że duży odsetek traktuje brytyjskość inkluzywnie, a wielu uważa się w takiej samej 
Tabela 1. Identyfikacja narodowa w Szkocji w latach 1996-2010 przy możliwości wyboru tylko jednej tożsamości (\%)

\begin{tabular}{|l|c|c|c|c|c|c|c|c|c|c|c|c|c|c|c|}
\hline \multirow{2}{*}{$\begin{array}{l}\text { tożsa- } \\
\text { mość }\end{array}$} & \multicolumn{10}{|c|}{ rok } \\
\cline { 2 - 9 } & $\mathbf{1 9 9 6}$ & $\mathbf{1 9 9 8}$ & $\mathbf{1 9 9 9}$ & $\mathbf{2 0 0 0}$ & $\mathbf{2 0 0 1}$ & $\mathbf{2 0 0 2}$ & $\mathbf{2 0 0 3}$ & $\mathbf{2 0 0 4}$ & $\mathbf{2 0 0 5}$ & $\mathbf{2 0 0 6}$ & $\mathbf{2 0 0 7}$ & $\mathbf{2 0 0 8}$ & $\mathbf{2 0 0 9}$ & $\mathbf{2 0 1 0}$ \\
\hline brytyjska & - & 20 & - & 17 & 13 & 16 & 18 & 20 & 19 & 14 & 14 & 19 & - & 15 & 19 \\
\hline szkocka & - & 72 & - & 77 & 80 & 77 & 75 & 72 & 75 & 79 & 78 & 72 & - & 73 & 73 \\
\hline
\end{tabular}

Źródło: opracowanie własne na podstawie danych z Office for National Statistics.

Tabela 2. Identyfikacja narodowa w Szkocji w latach 1997-2010 przy możliwości wyboru pełniejszego określenia tożsamości (\%)

\begin{tabular}{|l|c|c|c|c|c|c|c|c|c|c|}
\hline \multirow{2}{*}{ tożsamość } & \multicolumn{10}{|c|}{ rok } \\
\cline { 2 - 13 } & $\mathbf{1 9 9 7}$ & $\mathbf{1 9 9 9}$ & $\mathbf{2 0 0 0}$ & $\mathbf{2 0 0 1}$ & $\mathbf{2 0 0 3}$ & $\mathbf{2 0 0 5}$ & $\mathbf{2 0 0 6}$ & $\mathbf{2 0 0 7}$ & $\mathbf{2 0 0 9}$ & $\mathbf{2 0 1 0}$ \\
\hline szkocka nie brytyjska & 23 & 32 & 37 & 36 & 31 & 32 & 33 & 27 & 27 & 28 \\
\hline brytyjska nie szkocka & 4 & 4 & 4 & 3 & 4 & 5 & 5 & 6 & 4 & 4 \\
\hline bardziej brytyjska niż szkocka & 4 & 3 & 3 & 3 & 4 & 4 & 4 & 5 & 4 & 4 \\
\hline bardziej szkocka niż brytyjska & 38 & 35 & 31 & 30 & 34 & 32 & 32 & 30 & 31 & 30 \\
\hline obie jednakowo & 27 & 22 & 21 & 24 & 22 & 22 & 21 & 28 & 26 & 26 \\
\hline
\end{tabular}

Źródło: opracowanie własne na podstawie danych z Office for National Statistics.

mierze za Szkota, jak i Brytyjczyka, można uznać (przynajmniej w świetle tych wyników badań), że spora część populacji identyfikuje się jednak ze Zjednoczonym Królestwem.

Zupełnie inny jest charakter tożsamości walijskiej. Ze szkocką łączy ją jedynie pozostawanie w opozycji do wszystkiego co angielskie oraz nacjonalizm typu welfare, tzn. zwracanie uwagi na poziom życia społeczeństwa (Kaniasta 2010). Dla Walijczyków istotnym wyznacznikiem tożsamości narodowej oraz bardzo ważnym spoiwem społeczeństwa jest język walijski. Podobnie duże jest przywiązanie do symboli (por, żonkil, czerwony smok, strusie pióra czy potrójna harfa).

Składnikiem tożsamości Walijczyków, o wiele bardziej znaczącym niż gdziekolwiek indziej w Wielkiej Brytanii, jest religia. Według danych z 2001 r. (badania są dość rzadko w Walii przeprowadzane) 71,9 proc. populacji stanowili chrześcijanie, głównie anglikanie i pozostające w opozycji do Kościoła anglikańskiego (jako narzuconego przez Anglików) wyznania nonkonformistyczne, niosące przesłanie równości i brak podziału klasowego (Stats Wales 2001). Badanie przeprowadzone 10 lat później wykazało, że odsetek ten zmalał do 57,6 proc., co świadczy, że religia traci na znaczeniu jako główny składnik treści tożsamości walijskiej (Stats Wales 2011). Tożsamość walijska ujawnia się, także w zamiłowaniu do rugby, które uznawane jest za sport narodowy, oraz w kultywowaniu tradycji śpiewania (Kaniasta 2010). W przypadku badań identyfikacji narodowej, podobnie, jak w Szkocji, mieszkańcy Walii, poproszeni o wybór jednej tożsamości, w większości deklarowali walijską (tab. 3).

W badaniu, w którym możliwe było zadeklarowanie większej liczby tożsamości, wyłącznie walijską tożsamość wskazuje około 20-25 proc. mieszkańców (tabela 4). Podobne wskazania notuje opcja „bardziej walijska niż brytyjska", jednak nie są to odsetki tak wyraźnie przeważające nad odsetkiem osób deklarujących tożsamość brytyjską, jak w przypadku Szkocji. Około 10 proc. populacji uważa się za Brytyjczyków, zaś zarówno Brytyjczykiem, jak i Walijczykiem czuje się ponad 30 proc. respondentów. Można uznać, że podobnie jak w Szkocji, wzrasta identyfikacja $\mathrm{z}$ państwową tożsamością (brytyjskością).

Tożsamość Walijczyków jest bardziej etniczna. Religia, język i kultura odgrywają tu pierwszoplanową rolę, choć dużo słabszą niż kiedyś. Ponadto można $\mathrm{w}$ niej zaobserwować elementy społeczne, ukierunkowanie 
Tabela 3. Identyfikacja narodowa w Walii w latach 1996-2007 przy możliwości wyboru tylko jednej tożsamości (\%)

\begin{tabular}{|c|c|c|c|c|c|c|c|c|c|c|c|c|c|c|c|}
\hline \multirow{2}{*}{$\begin{array}{l}\text { tożsa- } \\
\text { mośćć }\end{array}$} & \multicolumn{15}{|c|}{ rok } \\
\hline & 1996 & 1997 & 1998 & 1999 & 2000 & 2001 & 2002 & 2003 & 2004 & 2005 & 2006 & 2007 & 2008 & 2009 & 2010 \\
\hline brytyjska & - & 26 & - & - & - & 31 & - & 31 & - & - & - & 27 & - & - & - \\
\hline walijska & - & 63 & - & - & - & 57 & - & 57 & - & - & - & 60 & - & - & - \\
\hline
\end{tabular}

Źródło: opracowanie własne na podstawie danych z Office for National Statistics.

Tabela 4. Identyfikacja narodowa w Walii w latach 1997-2007 przy możliwości wyboru pełniejszego określenia tożsamości (\%)

\begin{tabular}{|l|c|c|c|c|c|c|c|c|c|c|}
\hline \multirow{2}{*}{ tożsamość } & \multicolumn{9}{|c|}{ rok } \\
\cline { 2 - 13 } & $\mathbf{1 9 9 7}$ & $\mathbf{1 9 9 9}$ & $\mathbf{2 0 0 0}$ & $\mathbf{2 0 0 1}$ & $\mathbf{2 0 0 3}$ & $\mathbf{2 0 0 5}$ & $\mathbf{2 0 0 6}$ & $\mathbf{2 0 0 7}$ & $\mathbf{2 0 0 9}$ & $\mathbf{2 0 1 0}$ \\
\hline walijska nie brytyjska & 17 & 14 & - & 24 & 21 & - & - & 24 & - & - \\
\hline brytyjska nie walijska & 12 & 14 & - & 11 & 9 & - & - & 9 & - & - \\
\hline bardziej brytyjska niż walijska & 10 & 8 & - & 11 & 9 & - & - & 9 & - & - \\
\hline bardziej walijska niż brytyjska & 26 & 19 & - & 28 & 27 & - & - & 20 & - & - \\
\hline obie jednakowo & 34 & 37 & - & 28 & 29 & - & - & 32 & - & - \\
\hline
\end{tabular}

Źródło: opracowanie własne na podstawie danych z Office for National Statistics.

na działalność społeczeństwa obywatelskiego, jednak dużo słabiej rozwinięte niż w Szkocji.

W Irlandii Północnej z kolei tożsamość jest nieco bardziej złożona. Mieszkańcy postrzegają się jako Brytyjczycy lub Irlandczycy, co zazwyczaj ma związek z religią (protestanci i katolicy) bądź pochodzeniem etnicznym. Badania tożsamości w Irlandii Północnej przebiegają nieco inaczej niż ma to miejsce w Anglii, Szkocji i Walii. Już w tej ostatniej przeprowadza się je dość rzadko, a w Irlandii Północnej jeszcze rzadziej. Także inaczej formułowane są pytania. Najczęściej dotyczą one identyfikacji z Wielką Brytanią bądź Irlandią (ESRC 2010). W 2007 roku zaproponowano wybór pomiędzy tożsamościami „,brytyjska nie irlandzka” i ,bardziej irlandzka niż brytyjska". Opcja druga przeważyła w 5 proc. (19 proc. populacji czuje się bardziej Brytyjczykiem niż Irlandczykiem, natomiast 24 proc. odwrotnie). W 2010 roku zaproponowano więcej opcji i wówczas 37 proc. osób zadeklarowało tożsamość brytyjską, 26 proc. irlandzką, 29 proc. północno-irlandzką, zaś 3 proc. ulsterską (ESRC 2010).

W 2012 roku odnotowano wzrost odsetka osób deklarujących swoją tożsamość narodową jako irlandzką z 26 proc. w 2010, do 32 proc. w 2012 roku (ESRC 2012). To największy wzrost od 1989 roku, kiedy zaczęto prowadzić badania. Z kolei największy spadek odnotowano w odniesieniu do identyfikujących się $\mathrm{z}$ tożsamością północno-irlandzką, z najwyższego w historii - 29 proc. w 2010, do zaledwie 22 proc. w 2012 roku. Analiza powiązań pomiędzy tożsamością (tylko jedną do wyboru) ludności w Irlandii Północnej a wyznaniem prezentuje tabela 5 .

Protestanci w Irlandii Północnej w większości identyfikują się z brytyjską tożsamością, w około $1 / 4$ Z północno-irlandzką, w mniejszym stopniu z irlandzką. Z kolei katolicy wskazują tożsamość irlandzką (nawet w 70 proc.), albo północno-irlandzką, ale ta ostatnia odnotowała aż 10 proc. spadek w latach 2010-2012. Także poglądy polityczne w Irlandii Północnej związane są z wyznaniem religijnym jej mieszkańców, co zostanie przedstawione w dalszej części rozważań.

Interesujące są także dane $\mathrm{z}$ badania tożsamości ostatniego regionu Wielkiej Brytanii Anglii. W badaniach, w których można zadeklarować tylko jedną tożsamość, przeważają wskazania brytyjskie (tab. 6). Jednak, jak się okazuje, w zasadzie Anglicy (około 1/3) nie widzą różnicy pomiędzy byciem Anglikiem a Brytyjczykiem. Ilustrują to dane z tabeli 7 . 
Tabela 5. Identyfikacja narodowa w Irlandii Północnej w latach 1989-2012 (z podziałem na deklarowane wyznanie) $(\%)$

\begin{tabular}{|l|c|c|c|c|c|c|}
\hline \multirow{2}{*}{ rok } & \multicolumn{3}{|c|}{ protestanci } & \multicolumn{3}{c|}{ katolicy } \\
\cline { 2 - 7 } & brytyjska & irlandzka & $\begin{array}{c}\text { pólnocno- } \\
\text { irlandzka }\end{array}$ & brytyjska & irlandzka & $\begin{array}{c}\text { pólnocno- } \\
\text { irlandzka }\end{array}$ \\
\hline $\mathbf{1 9 8 9}$ & 66 & 4 & 16 & 10 & 60 & 25 \\
\hline $\mathbf{1 9 9 4}$ & 70 & 3 & 15 & 9 & 62 & 28 \\
\hline $\mathbf{1 9 9 8}$ & 67 & 3 & 18 & 8 & 65 & 24 \\
\hline $\mathbf{2 0 0 2}$ & 75 & 3 & 14 & 10 & 62 & 25 \\
\hline $\mathbf{2 0 0 5}$ & 63 & 6 & 24 & 8 & 60 & 20 \\
\hline $\mathbf{2 0 0 8}$ & 57 & 4 & 32 & 8 & 61 & 25 \\
\hline $\mathbf{2 0 1 0}$ & 60 & 3 & 29 & 7 & 58 & 26 \\
\hline $\mathbf{2 0 1 2}$ & 69 & 3 & 24 & 9 & 68 & 16 \\
\hline
\end{tabular}

Źródło: Northern Ireland Social Atitudes 1989;1994; Northern Ireland Life and Times Survey 1998-2012.

Tabela 6. Identyfikacja narodowa w Anglii w latach 1996-2010 przy możliwości wyboru tylko jednej tożsamości (\%)

\begin{tabular}{|c|c|c|c|c|c|c|c|c|c|c|c|c|c|c|c|}
\hline \multirow{2}{*}{$\begin{array}{l}\text { tożsa- } \\
\text { mośćć }\end{array}$} & \multicolumn{15}{|c|}{ rok } \\
\hline & 1996 & 1997 & 1998 & 1999 & 2000 & 2001 & 2002 & 2003 & 2004 & 2005 & 2006 & 2007 & 2008 & 2009 & 2010 \\
\hline brytyjska & 58 & 55 & 51 & 44 & 47 & 44 & 51 & 48 & 51 & 48 & 39 & 47 & 45 & 46 & 52 \\
\hline angielska & 34 & 33 & 37 & 44 & 41 & 43 & 37 & 38 & 38 & 40 & 47 & 39 & 41 & 41 & 34 \\
\hline
\end{tabular}

Źródło: opracowanie własne na podstawie danych z Office for National Statistics.

Tabela 7. Identyfikacja narodowa w Anglii w latach 1997-2007 przy możliwości wyboru pełniejszego określenia tożsamości (\%)

\begin{tabular}{|l|c|c|c|c|c|c|c|c|c|c|}
\hline \multirow{2}{*}{ tożsamośćc } & \multicolumn{10}{|c|}{ rok } \\
\cline { 2 - 15 } & $\mathbf{1 9 9 7}$ & $\mathbf{1 9 9 9}$ & $\mathbf{2 0 0 0}$ & $\mathbf{2 0 0 1}$ & $\mathbf{2 0 0 3}$ & $\mathbf{2 0 0 5}$ & $\mathbf{2 0 0 6}$ & $\mathbf{2 0 0 7}$ & $\mathbf{2 0 0 9}$ & $\mathbf{2 0 1 0}$ \\
\hline angielska nie brytyjska & 7 & 17 & 18 & 17 & 17 & - & - & 19 & - & - \\
\hline brytyjska nie angielska & 7 & 14 & 12 & 11 & 10 & - & - & 14 & - & - \\
\hline bardziej brytyjska niż angielska & 14 & 11 & 14 & 9 & 13 & - & - & 14 & - & - \\
\hline bardziej angielska niż brytyjska & 17 & 14 & 14 & 13 & 19 & - & - & 14 & - & - \\
\hline obie jednakowo & 45 & 37 & 34 & 42 & 31 & - & - & 31 & - & - \\
\hline
\end{tabular}

Źródło: opracowanie własne na podstawie danych z Office for National Statistics.

\section{Dewolucja jako rezultat działań tożsamości pogranicznych}

Różne pod względem genezy, struktury i motywacji tożsamości społeczności zamieszkujących regiony Wielkiej Brytanii powodowały (i powodują) artykułowanie odmiennych potrzeb. Stanowiły jednak i stanowią nadal, siłę na tyle liczącą się, że należało uwzględnić ich interesy i znaleźć rozwiązanie ustrojowe, które pozwoliłoby to zrobić w możliwie najlepszy sposób. Entuzjazm dla rozwiązań dających samodzielność poszczególnym regionom także był zróżnicowany - najsilniejszy w Szkocji, daleko mniejszy w Walii, czy Irlandii Północnej, zaś Anglia - i jako całość, i jako region wykazywała bardzo małą inklinację w stronę dewolucji (Tierney 2009).

Z uwagi na różnorodność obszarów stanowiących części składowe Zjednoczonego Królestwa, a w związku $\mathrm{z}$ tym odmienne potrzeby, dewolucja została przeprowadzona w sposób taki, by dopasować go do wymagań różnorodności tożsamościowej. Należy stwierdzić, że dewolucja jest przede wszystkim rezultatem kompromisu pomiędzy dążeniami 
separatystycznymi poszczególnych części Zjednoczonego Królestwa, a utrzymaniem pełni władzy przez parlament i rząd Zjednoczonego Królestwa. Wynikła także z potrzeb przeprowadzenia dewolucji ustawodawczej w momencie osiągnięcia limitów dewolucji biurokratycznej (Kalupa 2010). Taki model podziału władzy jest ze wszech miar korzystny, jeśli chodzi o sprawność rządzenia.

Rzecz w tym, że w warunkach brytyjskich wprowadzenie go zaowocowało pewną asymetrią, ponieważ model nie objął wszystkich obszarów (Tierney 2009). Nie przesądza to jeszcze o niestabilności, natomiast może ją powodować. Anglia nie dążyła do samodzielności, ponieważ, jak się wydawało, wcale tego nie potrzebowała. Tymczasem pojawiła się kwestia tzw. West Lothian lub English Question dotycząca paradoksu, konstytucyjnej anomalii wynikającej właśnie $\mathrm{z}$ asymetrii dewolucji. Polega ona na ułomności w zakresie reprezentacji w parlamencie każdej części składowej Zjednoczonego Królestwa, oprócz tej obdarzonej dewolucją $\mathrm{w}$ największym stopniu. Wytworzyła się sytuacja, w której członek parlamentu wybrany w Szkocji, Walii czy Irlandii Północnej, może wypowiadać się i głosować w sprawach dotyczących Anglii, ale członek parlamentu wybrany $\mathrm{w}$ angielskim okręgu wyborczym, nie może wypowiadać się i głosować w tych samych sprawach, dotyczących samodzielnych terytoriów, ponieważ akurat zostały one przeznaczone do rozstrzygania np. w Parlamencie Szkockim albo Zgromadzeniu w Cardiff lub Belfaście (Deacon i Pilkington 2006).

Z drugiej strony, w Szkocji (podobnie jak dla Wielkiej Brytanii jako całości) ciało dysponujące uprawnieniami legislacyjnymi nosi nazwę Parlamentu, podczas gdy w Walii czy Irlandii Północnej przyjęły nazwę Zgromadzenia. To wyraz siły tożsamości w kształtowaniu władztwa nad terytorium, z którym odczuwa więź, zaawansowania zaangażowania $\mathrm{w}$ jego polityczne, społeczne i ekonomiczne funkcjonowanie.

Ustawy dewolucyjne nie wystarczyły do klarownego określenia zasad rządzących tym procesem, dlatego zawarto międzypartyjne porozumienie (Memorandum of Understanding), oraz przyjęto konwenanse konstytucyjne (m.in. konwenans Sewela). Co więcej, wciąż pojawiają się nowe propozycje zmian dotyczących poszerzenia zakresu sfer objętych dewolucją (Kalupa 2010).

Można uznać, że ustrój polityczny Wielkiej Brytanii jest w głównej mierze rezultatem aktywności politycznej tożsamości brytyjskich regionów, wspartej dodatkowo obecnością w Unii Europejskiej, która umożliwia narodom bez państwa a nawet grupom etnicznym na samodzielne funkcjonowanie, chociaż nie można wykluczyć, że i bez tego wpływu taki zabieg ustrojowy zostałby przeprowadzony. Tym niemniej jednak brytyjskie samodzielne regiony odnalazły się na forum europejskim delegując tam swoich, niezwiązanych z Wielką Brytanią, przedstawicieli.

\section{Tożsamość a poglądy polityczne}

Poszczególne regiony Wielkiej Brytanii, choć wydają się jednolite, bynajmniej homogeniczne nie są, i poglądy co do dalszych ich losów także nie są spójne. Gdyby było inaczej, nie zastanawiano by się nad tym, jaki będzie wynik referendum w Szkocji. Skomplikowana tożsamość pogranicza znajduje odzwierciedlenie w poglądach politycznych. Przykładowo identyfikacja narodowa Szkotów wyrażana jest przez konkretne poglądy polityczne i wiąże się z określonymi zachowaniami wyborczymi. Bycie Szkotem tożsame jest $\mathrm{z}$ wyznawaniem przede wszystkim centrolewicowych poglądów (Kalupa 2010). Jednak błędem byłoby jednoznaczne twierdzenie, że relacja między tożsamością i postawami politycznymi jest jednoznaczna.

$Z$ tabeli 8 wynika, że im większa identyfikacja $\mathrm{z}$ tożsamością szkocką, a mniejsza z brytyjską, tym większe poparcie dla niepodległości. Trudno jednak powiedzieć, że zależność jest prosta. Oczywiste jest, że niewielu deklarujących silne więzi z tożsamością brytyjską chciałoby szkockiej niepodległości. Niepodległości chce jednak tylko około połowy z tych, którzy zaprzeczają konotacjom brytyjskim, oraz co czwarty obywatel Szkocji, określający swoją tożsamość jako bardziej szkocką niż brytyjską.

Wydaje się, że wpływ tożsamości na poglądy ludzi w sprawie losów Szkocji, sposobów 
Tabela 8. Relacje między identyfikacją narodową a preferencjami politycznymi w sprawie niepodległości Szkocji (1999-2012) (\%)

\begin{tabular}{|l|c|c|c|c|c|c|}
\hline tożsamość & $\mathbf{1 9 9 9}$ & $\mathbf{2 0 0 3}$ & $\mathbf{2 0 0 5}$ & $\mathbf{2 0 0 7}$ & $\mathbf{2 0 1 1}$ & $\mathbf{2 0 1 2}$ \\
\hline szkocka nie brytyjska & 44 & 47 & 51 & 45 & 53 & 46 \\
\hline bardziej szkocka niż brytyjska & 26 & 22 & 34 & 25 & 33 & 23 \\
\hline zarówno szkocka jak brytyjska & 10 & 8 & 20 & 6 & 12 & 11 \\
\hline bardziej brytyjska niż szkocka & 4 & 5 & 15 & 7 & 11 & 12 \\
\hline brytyjska nie szkocka & 8 & 10 & 22 & 10 & 9 & 6 \\
\hline
\end{tabular}

Źródło: opracowanie własne na podstawie danych z Office for National Statistics.

rządzenia, maleje i nie jest taki, jak u progu dewolucji, gdy Parlament w Szkocji rozpoczynał swoje funkcjonowanie. Zwraca uwagę, że w zasadzie poparcie dla niepodległości w każdej opcji tożsamościowej pod względem proporcji pozostaje mniej więcej niezmienne (a nawet nieco spadło) na przestrzeni ostatnich czternastu lat. Nie oznacza to jednak, że osoby silnie identyfikujące się ze szkocką tożsamością są bardziej skłonne opowiedzieć się za kontynuacją funkcjonowania w Unii.

Wśród preferencji co do rozwiązań systemowych w Szkocji, dewolucja jest najpopularniejsza. Za niepodległością zwykle opowiada się około 25-30 proc., a żadnego Parlamentu Szkocji nie chce tylko co dziesiąta osoba. Trudno powiedzieć, czy sukces Narodowej Partii Szkocji w 2007 i w 2011 roku, skutkujący rozpisaniem referendum, był spowodowany wzrostem poparcia dla niepodległości. Właściwie pomiędzy 1999 a 2006 r. poparcie to kształtowało się na poziomie 30 proc, zaś po dojściu Szkockiej Partii Narodowej (Scottish National Party, SNP) do władzy spadło do 26 proc. Być może sama świadomość, że w Zjednoczonym Królestwie, w tych warunkach politycznych, partia taka jak SNP może skutecznie działać, każe zastanowić się nad zasadnością niepodległości. Ponadto, trzy wiodące partie w Szkocji, popierające dalsze funkcjonowanie Szkocji w ramach Wielkiej Brytanii, przygotowują plany dalszej dewolucji, co świadczy, że wynik nie jest tak oczywisty.

W Irlandii Północnej natomiast, zauważalne są zmiany $\mathrm{w}$ relacji pomiędzy tożsamością a preferencjami dotyczącymi rozwiązań ustrojowych. Najbardziej wyraźnie są widoczne w odniesieniu do poparcia dążeń niepodległościowych (British Social Attitudes 2013). Ich poziom był niski wśród osób o brytyjskiej tożsamości między 1989 a 1998 rokiem, po czym (wówczas podpisano porozumienie Good Friday, konsolidujące proces pokojowy w Irlandii Północnej) wzrósł dwukrotnie, aby wrócić do poziomu sprzed 1998 roku w 2008. Odwrotna, choć dużo mniej wyraźna, jest zmiana trendu poparcia dla niepodległości wśród osób deklarujących irlandzką narodowość. Po 2007 r. ta grupa zwiększyła poparcie dla pozostania $\mathrm{W}$ Wielkiej Brytanii. Ogólnie związek pomiędzy tożsamością a poparciem dla pozostania częścią Zjednoczonego Królestwa jest jednak nieco słabszy niż w 1989 roku (tamże).

Tabela 9. Poparcie dla opuszczenia przez Irlandię Pólnocną Wielkiej Brytanii (niezależność/re-unifikacja z Irlandią) w latach 1989-2012 (\%)

\begin{tabular}{|l|c|c|c|}
\hline \multirow{2}{*}{ rok } & \multicolumn{3}{|c|}{ tożsamość } \\
\cline { 2 - 4 } & brytyjska & irlandzka & $\begin{array}{c}\text { północno- } \\
\text { irlandzka }\end{array}$ \\
\hline $\mathbf{1 9 8 9}$ & 4 & 65 & 26 \\
\hline $\mathbf{1 9 9 3}$ & 3 & 64 & 24 \\
\hline $\mathbf{1 9 9 6}$ & 4 & 58 & 28 \\
\hline $\mathbf{1 9 9 8}$ & 5 & 67 & 27 \\
\hline $\mathbf{2 0 0 0}$ & 8 & 67 & 30 \\
\hline $\mathbf{2 0 0 3}$ & 8 & 68 & 33 \\
\hline $\mathbf{2 0 0 6}$ & 8 & 68 & 34 \\
\hline $\mathbf{2 0 0 7}$ & 8 & 61 & 24 \\
\hline $\mathbf{2 0 0 8}$ & 7 & 57 & 16 \\
\hline $\mathbf{2 0 0 9}$ & 4 & 56 & 13 \\
\hline $\mathbf{2 0 1 0}$ & 5 & 46 & 17 \\
\hline $\mathbf{2 0 1 2}$ & 5 & 46 & 15 \\
\hline
\end{tabular}

Źródło: British Social Attitudes.

Tymczasem poparcie dla wyjścia z Unii Brytyjskiej najwyższe jest wśród deklarujących się jako Irlandczycy. Jednak widać spadek poparcia dla tej opcji, zwłaszcza od 2007 roku 
(tabela 9). Obecnie ten pomysł popiera mniej niż połowa z nich. Podobnie Północni Irlandczycy, początkowo niemal w $1 / 3$ wspierali opuszczenie UK, obecnie zaś zaledwie w 15 proc., być może częściowo dlatego, że wielu z nich to protestanci. Debata na temat przyszłości ustrojowej regionu wydaje się mniej spolaryzowana pomiędzy tymi dwiema tożsamościami.

Porównując poparcie dla pozostania w Wielkiej Brytanii z wyznaniem, należy stwierdzić, że jest ono największe u nieopowiadających się za żadną religią oraz u osób wyznania protestanckiego, choć zmieniało się w czasie (tabela 10).

Tabela 10. Poparcie dla pozostania Irlandii Północnej w Wielkiej Brytanii 1989-2012 (\%)

\begin{tabular}{|l|c|c|c|}
\hline \multirow{2}{*}{ rok } & \multicolumn{3}{|c|}{ wyznanie } \\
\cline { 2 - 4 } & $\begin{array}{c}\text { protestanc- } \\
\text { ka }\end{array}$ & katolicka & $\begin{array}{c}\text { bez } \\
\text { wyznania }\end{array}$ \\
\hline $\mathbf{1 9 8 9}$ & 93 & 32 & 83 \\
\hline $\mathbf{1 9 9 3}$ & 89 & 36 & 71 \\
\hline $\mathbf{1 9 9 6}$ & 85 & 35 & 54 \\
\hline $\mathbf{1 9 9 8}$ & 84 & 19 & 58 \\
\hline $\mathbf{2 0 0 0}$ & 83 & 20 & 53 \\
\hline $\mathbf{2 0 0 3}$ & 82 & 21 & 45 \\
\hline $\mathbf{2 0 0 6}$ & 85 & 22 & 46 \\
\hline $\mathbf{2 0 0 7}$ & 89 & 39 & 71 \\
\hline $\mathbf{2 0 0 8}$ & 89 & 43 & 71 \\
\hline $\mathbf{2 0 0 9}$ & 91 & 47 & 66 \\
\hline $\mathbf{2 0 1 0}$ & 91 & 51 & 60 \\
\hline $\mathbf{2 0 1 2}$ & 86 & 42 & 65 \\
\hline
\end{tabular}

Źródło: British Social Attitudes.

Widać wyraźnie, że poparcie to jest małe tylko u osób wyznania katolickiego, ale na przestrzeni lat rosło. Spadek (duży, bo dziewięcioprocentowy) odnotowano w 2012 roku, w porównaniu z rokiem 2010. Nieco mniejszy, bo 5-procentowy spadek aprobaty dla pozostania zanotowano też wśród protestantów. Wzrósł natomiast odsetek poparcia ze strony bezwyznaniowców (również o 5 proc.). Kwestia statusu ustrojowego Irlandii Północnej pozostaje źródłem podziałów w tej regionalnej społeczności.

W Walii poparcie dla niezależności jest dość słabe, nawet wśród określających się tylko jako Walijczycy. Najpopularniejszą opcją dla wyłącznie walijskiej albo podwójnej tożsamości jest rozszerzenie dewolucji na wzór szkocki. Deklarujący tylko brytyjską opcję są podzieleni, ale większość preferuje jakąś formę dewolucji. 32 proc. $\mathrm{z}$ nich nie chce żadnego walijskiego Zgromadzenia (tabela 11).

Tabela 11. Preferencje w odniesieniu do rozwiązań konstytucyjnych w Walii według identyfikacji narodowościowej (\%)

\begin{tabular}{|l|c|c|c|}
\hline \multirow{2}{*}{$\begin{array}{l}\text { Propozycja } \\
\text { rozwiązania } \\
\text { konstytucyjnego }\end{array}$} & $\begin{array}{c}|c| \\
\text { tylko } \\
\text { walijska }\end{array}$ & $\begin{array}{l}\text { walijska i } \\
\text { brytyjska }\end{array}$ & $\begin{array}{c}\text { tylko } \\
\text { brytyjska }\end{array}$ \\
\cline { 2 - 4 } Parlament Walijski & 42 & 36 & 29 \\
\hline $\begin{array}{l}\text { Walijskie } \\
\text { Zgromadzenie } \\
\text { Narodowe }\end{array}$ & 19 & 29 & 1 \\
\hline niepodleglość & 19 & 10 & 5 \\
\hline $\begin{array}{l}\text { brak Walijskiego } \\
\text { Zgromadzenia } \\
\text { Narodowego }\end{array}$ & 15 & 20 & 32 \\
\hline
\end{tabular}

Źródło: Rosie i Bond 2012.

Anglia, chociaż nie jest objęta dewolucją, generuje poglądy na kwestie tego procesu. Dotyczą one m.in. poparcia dla szkockiej niezależności, czy zapatrywań na wydatki Szkocji. Najważniejsze jest jednak, co sądzą Anglicy o objęciu także ich dewolucją.

Ci, którzy uważają się za Anglików, ale nie Brytyjczyków wykazują tendencję do utworzenia Angielskiego Parlamentu i mniejszą skłonność (spadającą co pięć lat o około 5 proc.) do popierania obecnego stanu rzeczy (British Social Attitudes 2013). U deklarujących tożsamość brytyjską nie angielską także nie widać szczególnej tendencji do zmian. Także i tu akceptacja dla istniejącej sytuacji maleje, jednak wolniej, bo o około 3-4 proc. co 5 lat. W 2012 r. 10 proc. mniej osób o identyfikacji angielskiej nie brytyjskiej, niż tych o tożsamości brytyjskiej nie angielskiej nie widzi konieczności jakichkolwiek modyfikacji ustrojowych w odniesieniu do Anglii (odpowiednio 49 i 59 proc.).

Jak wynika $\mathrm{z}$ tabeli 12, większy jest odsetek osób uważających się za Anglików, 
Tabela 12. Poparcie dla rozwiązań ustrojowych w Anglii wedlug identyfikacji narodowościowej (\%)

\begin{tabular}{|c|c|c|c|c|c|}
\hline \multicolumn{6}{|c|}{ tożsamość } \\
\hline & $\begin{array}{l}\text { angielska nie } \\
\text { brytyjska }\end{array}$ & $\begin{array}{c}\text { bardziej } \\
\text { angielska niż } \\
\text { brytyjska }\end{array}$ & obie jednakowo & $\begin{array}{c}\text { bardziej } \\
\text { brytyjska niż } \\
\text { angielska }\end{array}$ & $\begin{array}{l}\text { brytyjska nie } \\
\text { angielska }\end{array}$ \\
\hline \multicolumn{6}{|c|}{ popierający status quo } \\
\hline 1999 & 59 & 63 & 61 & 71 & 65 \\
\hline 2007 & 54 & 52 & 61 & 66 & 61 \\
\hline 2012 & 49 & 54 & 57 & 64 & 59 \\
\hline \multicolumn{6}{|c|}{ popierający utworzenie Parlamentu Angielskiego } \\
\hline 1999 & 23 & 19 & 18 & 11 & 17 \\
\hline 2007 & 28 & 23 & 14 & 20 & 9 \\
\hline 2012 & 34 & 26 & 20 & 16 & 16 \\
\hline
\end{tabular}

Źródło: British Social Attitudes 2013.

nie Brytyjczyków popierających Angielski Parlament, niż wśród przyznających się do identyfikacji brytyjskiej nie angielskiej. Wśród tych pierwszych akceptacja wzrasta sukcesywnie - między 1999 a 2007 rokiem o 5 proc., zaś między 2007 a 2012 rokiem o 6 proc. $\mathrm{Ci}$, deklarujący się jako Brytyjczycy nie Anglicy w ciągu ośmiu lat pomiędzy 1999 a 2007 rokiem wykazywali aż 8-procentowe spadające poparcie dla Parlamentu Anglii. Jednak do roku 2012 wzrosło ono do niemal tego samego poziomu, który odnotowano w 1999 roku (16 proc). Przy tym w 2012 roku dwa razy więcej respondentów o orientacji angielskiej nie brytyjskiej chętnie widziałaby oddzielny dla tej części kraju Parlament (34 proc.).

$\mathrm{Z}$ danych nie wynika wyraźnie, by zanosiło się na to, żeby angielska identyfikacja narodowościowa (choć poparcie w kwestii zmian rośnie) stała się jakąś liczącą się siłą polityczną w walce o objęcie Anglii dewolucją.

Ustalenia powyższe pozwalają stwierdzić, że zaprezentowane dane może nie świadczą dobitnie o szczególnej sile politycznej tożsamości narodowych w Zjednoczonym Królestwie Wielkiej Brytanii i Irlandii Północnej, ale na pewno kontrasty tożsamościowe, odmienne polityczne wzorce w poszczególnych regionach Wielkiej Brytanii, są brane pod uwagę i interpretowane przy politycznych i ustrojowych rozwiązaniach.

\section{Proces dewolucji a zmiany tożsamości pogranicza}

W 1995 roku George Robertson, szkocki polityk, członek Partii Pracy powiedział, że dewolucja uśmierci nacjonalizm (Black 2011). Wprawdzie wypowiedź miała ironiczny charakter, ale okazuje się zawierać w sobie nieco racji. Dla niniejszych rozważań istotne jest zbadanie, czy istnieje, a jeśli tak, to jaki, zwrotny wpływ dewolucji na tożsamości regionów Wielkiej Brytanii (brytyjskiego pogranicza).

Wystarczy spojrzeć na tabele numer 2,4,7, żeby zauważyć, że mieszkańcy Walii, Szkocji, Irlandii Północnej coraz rzadziej deklarują przywiązanie do jednej tylko tożsamości. Nawet w Szkocji, w której jest to trend silny, rośnie odsetek wskazań na opcję narodową oraz brytyjską. Bycie Brytyjczykiem oznacza identyfikację z Wielką Brytanią jako całością, a więc dewolucja, przy możliwości wystąpienia tendencji separatystycznych, unifikuje kraj. Wielka Brytania, dając swobodę odmiennym terytoriom, dzieląc się władzą, zyskała coś bardzo wartościowego: uświadomiła mieszkańcom i liderom regionów, i utrwaliła to przekonanie, że dla realizacji ich interesów nie jest im potrzebne własne państwo, skoro w ramach Unii Brytyjskiej osiągają te same cele korzystając ze wsparcia zarówno Zjednoczonego Królestwa, jak i Unii Europejskiej, która traktuje je jak samodzielne podmioty. 


\section{Wnioski}

Nie ulega wątpliwości, że tożsamość pogranicza w Wielkiej Brytanii odgrywa dość dużą i coraz większą rolę $\mathrm{w}$ kształtowaniu rzeczywistości politycznej. Odmienności regionów, siła artykulacji własnych interesów w dużej mierze przesąadziła o obecnym kształcie Zjednoczonego Królestwa. Oczywiście nie był to jedyny czynnik; należy pamiętać o braku wydolności scentralizowanej administracji. Nie bez znaczenia były także ogólnoeuropejskie tendencje $\mathrm{ku}$ wspieraniu regionalizmów, a wielka Brytania jako członek Unii Europejskiej, także uczestniczyła w realizacji jej polityki regionalnej. Istotną sprawą jest tu także charakter ustawy zasadniczej, która dzięki brakowi formalizmu, pozwoliła przeprowadzić proces dewolucji dość sprawnie oraz pozostawia otwartą drogę do wprowadzania zmian $\mathrm{w}$ trakcie ewolucji procesu.

Jednocześnie zauważalny jest (subtelny na razie) wpływ dewolucji na zmiany tożsamości. Coraz więcej mieszkańców obok identyfikacji narodowej (regionalnej), związanej z zamieszkiwanym terytorium, wskazuje także na związki z Wielką Brytanią jako całością, co pozwala wierzyć, że droga, którą obrało Zjednoczone Królestwo, dzieląc się władzą była właściwa i jedności państwa, przynajmniej na razie, nic nie zagraża.

\section{Literatura:}

Anzaldūa, G. (1999). Borderlands - La Frontera: The New Mestiza. San Francisco: Aunt Lute Books.

Babiński, G. (1997). Pogranicze polsko-ukraińskie: etniczność, zróżnicowanie religijne, tożsamość. Kraków: Nomos.

Ball, A. (2005). Writing in the Margins: Exploring the Borderland in the Work of Janet Frame and Jane Campion Borders and Boundaries. eSharp, $n r$ 5. Pobrano 24.11.2013, z: http://www.gla.ac.uk/ departments/esharp/issues/5/.

Black, A. (2011). Q\&A: Scottish independence referendum. Pobrano 24.11.2013, z: http://www.bbc. co.uk/news/uk-scotland-13326310 .

Bogdanon, V. (2001). Devolution in the United Kingom. Oxford: Oxford University Press.

Bokszański, Z. (1989). Tożsamość - interakcja - grupa. Tożsamość jednostki w perspektywie teorii socjologicznej. Łódź: Wydawnictwo Uniwersytetu Łódzkiego.

Borderlands Borders and Global Frontiers - Defining Borders_Borderlands_And Frontiers - Land, Control,Peoples, and Rights. Pobrano 24.112013, z: http://science jrank org/pages/8485/BordersBorderlands-Frontiers-Global-Defining-Borders-Borderlands-Frontiers.htmI\#ixzz2n8wqnLKd.

NatCen Social Research (2013) British Social Attitude Pobrano 24.112013, z: http://www.bsa-30. natcen.ac.uk/read-the-report/devolution/constitutional-preferences.aspx.

Buczek, K. (1964). O regionach historycznych. Małopolskie Studia Historyczne, z. 3-4.

Office for National Statistics (2011) Census 2011. Pobrano 1.12.2013, z: http://www.ons.gov.uk ons/rel/census/2011-census/index.html.

Cole, A (2006). Beyond Devolution and Decentralisation: Building Regional Capacity in Wales and Brittany. Manchester Univesity Press.

Czapiewski, T. (2011). Ksztaltowanie się systemu politycznego Szkocji. Szczecin: PPH ZAPOL.

Deacon, R., Pilkington, C. (2006). Devolution in Britain Today. Manchester: Manchester University Press.

Deacon, B., Cole, D., Tregidga, G. (2003). Mebyon Kernow and Cornish Nationalism. Cardiff: Welsh Academic Press.

Dunaj, B. (red.). (1998). Stownik wspótczesnego języka polskiego. t. II. Warszawa: Reader's Digest Przegląd.

Fealty, M. (2009) The 'Gaelic Irish' versus the 'Ulster Scots' is a dangerous illusion. Pobrano 2122013 , z: http.//sluggerotoole.com/2009/09/01/the-gaelic-irish-versus-the-ulster-scots-is-adangerous-illusions. 
Ferguson, C. (2009). Why aren't the Cornish recognised as a national minority? The Guardian Pohrano 1.12.2013, z: http///www.theguardian.com/commentisfree/libertycentral/2009/sep/08/ cornwall-national-minority-race.

Gątkiewicz, P., Kocon, M., Skowron, B. (2013) Problematyka ,obcego" a kwestia pogranicza - analiza socjologiczna. Pobrano 1.12.2013, z: www.socjologia.ath.bielsko.pl/prace/konferencje/index.pdt

Keating, M. (2001). Nations against the State. The New politics of nationalism in Quebec, Catalonia and Scotland. New York: Palgrave.

Kalupa, A. (2010). Tożsamość Szkotów - etniczna czy obywatelska? Spoleczeństwo i Polityka, nr 4 (25).

Kaniasta, M. (2010). Etniczność jako podstawa samookreślenia i odrodzenia kulturowego Walijczyków. Społeczeństwo i Polityka, nr 4 (25).

Leszczycki, S. (1965). Zadania regionalizacji ekonomicznej. Przeglad Geograficzny, nr 2, s. 273-293.

Morrow, D. (2013). Northern Ireland remains sharply divided over national identity but with no strong desire for Irish unity Relfast Telegraph Pohrano $24112013, z \cdot$ http.//www helfasttelegraph $\mathrm{co} \mathrm{uk} /$ dehateni/hlogs/northern-ireland-remains-sharply-divided-over-national-identity-but-with-nostrong-desire-for-irish-unity-29332675.htm

Petrozolin-Skowrońska, B. (1996). Nowa encyklopedia powszechna PWN, t. 5. Warszawa: Wydawnictwo Naukowe PWN.

Romanowicz, W. (2006). Pogranicze jako przedmiot badań społecznych. Radzyński Rocznik Humanistyczny, tom 4.

Rosie, M., Bond, R. (2012). National Identities and Politics after Devolution, Radical Statistics, $n r 97$.

Sadowski, A. (2008). Pogranicze - pograniczność - tożsamość pograniczna. Pogranicze. Studia Spoleczne, t. XIV, s. 17-30.

Simonides, D. (1994). Archaizmy kulturowe na śląskim pograniczu. W: T. Smolińska, (red.), Pogranicze jako problem kultury. Opole: Wydawnictwo Uniwersytetu Opolskiego.

Stats Wales (2001) Religion by area and measure Pohrang 1.12.2013, z: http://www.statswales. wales.gov.uk/TableViewer/tableView.aspx?ReportId=3581.

Stats Wales (2011) Welsh residents by religion and local authority Pohrano 112.2013, z: https:// statswales.wales.gov.uk/Catalogue/Census/2011/Welsh-Residents-by-Religion.

Szczepański, M. (1997). Region pogranicza i pogranicze w regionie Gazeta Uniwersytecka Uniwersytetu Ślaskiego. Pobrano 1.12.2013, z: http://gu.us.edu.pl/node/241781.

ESRC (2013) The Northern Ireland Life and Times survey Pohrano 1 12.2013, z: http://www.ark. ac.uk/sol/surveys/community_relations/time_series/CRencyidentity.htm.

Tierney, S. (2009). Federalism in a Unitary State; a Paradox too Far? Regional and Federal Studies, t.19, $n r$ 2, s. 237-253.

Wilson, T., Donnan, H. (2012). A companion to border studies. Wiley-Blackwell Oxford.

Wilson T., Donnan H. (2000). Border identities. Nation and state at international frontiers. Cambridge: Cambridge University Press.

Zartman I.W. (2010). Understanding life in the borderlands. Boundaries in depth and in motion. Athens, Georgia: University of Georgia Press. 